\title{
THE FEMINIZATION OF PRIMARY EDUCATION: EFFECTS OF TEACHERS' SEX ON PUPIL ACHIEVEMENT, ATTITUDES AND BEHAVIOUR
}

\author{
GEERT DRIESSEN
}

\begin{abstract}
Since the mid-1990s, considerable concern has been expressed about the feminization of education. The underlying assumption is that the increasing number of female teachers is leading to a lack of male role models, which may then have negative consequences for the achievement and behaviour of boys in particular. For this reason, policy is currently being pursued in several countries to increase the number of male teachers. In the present article, the theoretical foundation for this policy will be shown to be weak at best. To test this empirically, a large-scale study of Dutch primary schools was conducted, which involved 5181 grade eight pupils, 251 teachers and 163 schools. This study confirmed that teacher sex has no effect whatsoever on the achievement, attitudes or behaviour of pupils. This finding holds for both boys and girls, for both minority and non-minority pupils and for both children from lower and higher socialeconomic milieus.
\end{abstract}

Zusammenfassung - DIE VERWEIBLICHUNG DER HAUPTSCHULBILDUNG: DIE AUSWIRKUNGEN DER GESCHLECHTSZUGEHÖRIGKEIT DER LEHRKRÄFTE AUF LEISTUNG, EINSTELLUNGEN UND VERHALTEN DER SCHÜLER - Seit Mitte der neunziger Jahre wurden immer wieder erhebliche Bedenken gegen die Verweiblichung der Schulbildung erhoben. Dem liegt die Annahme zu Grunde, dass die wachsende Anzahl weiblicher Lehrkräfte zu einem Mangel an männlichen Rollenvorbildern führe, welcher sich negativ auf die Leistungen und das Verhalten besonders der Jungen auswirke. Aus diesem Grund verfolgen mehrere Länder derzeit die Politik, die Zahl der männlichen Lehrkräfte zu erhöhen. Der vorliegende Artikel zeigt, dass die theoretische Grundlage dieser Politik auf sehr schwachen Füssen steht. Zum empirischen Nachweis diente eine Breitenuntersuchung in holländischen Hauptschulen, in welche 5181 Achtklässler, 251 Lehrkräfte und 163 Schulen einbezogen waren. Die Studie ergab, dass die Geschlechtszugehörigkeit der Lehrkräfte keine wie immer gearteten Auswirkungen auf Leistung, Einstellungen und Verhalten der Schüler hat. Dies betrifft sowohl Jungen wie Mädchen, Minderheiten wie Nicht-Minderheiten sowie Kinder aus niedrigerem wie höherem sozialökonomischen Milieu.

Résumé - LA FÉMINISATION DE L'ÉDUCATION PRIMAIRE: EFFETS DU SEXE DES PROFESSEURS SUR L'ACCOMPLISSEMENT, LES ATTITUDES ET LE COMPORTEMENT DES ÉLÈVES - Depuis le milieu des années 90, on a exprimé de grandes inquiétudes à propos de la féminisation de l'éducation. L'hypothèse sousjacente est que le nombre croissant de professeurs féminins conduit à un manque de modèles du rôle masculin, ce qui pourrait alors avoir des conséquences négatives sur l'accomplissement et le comportement des garçons en particulier. Pour cette raison, on poursuit actuellement dans plusieurs pays une politique visant à augmenter le nombre de professeurs masculins. Dans le présent article, on montrera que la base théorique de 
cette politique s'avère faible tout au mieux. Pour vérifier ceci sur le plan empirique, on a entrepris une étude à grande échelle sur les écoles primaires hollandaises, impliquant 5181 élèves du niveau 8, 251 professeurs et 163 écoles. Cette étude a confirmé que le sexe du professeur n'a aucun effet quel qu'il soit sur l'accomplissement, les attitudes ou le comportement des élèves. Ce résultat vaut pour les garçons et les filles, pour les élèves de minorité ou non, et pour les enfants de milieux sociaux-économiques les plus faibles comme les plus élevés.

Resumen - LA FEMINIZACIÓN DE LA EDUCACIÓN PRIMARIA: INFLUENCIA DEL GÉNERO DE LOS DOCENTES SOBRE EL RENDIMIENTO, LAS ACTITUDES Y LA CoNDUCTA DE LOS ALUMNOS-Desde mediados de los noventa se viene manifestando una considerable preocupación sobre la feminización en la enseñanza escolar, en el sentido de que un creciente número de docentes femeninas pueda causar una falta de modelos masculinos y que esta falta podría tener consecuencias negativas para el rendimiento y la conducta de los alumnos, particularmente de los varones. Por esta razón, en varios países se está siguiendo la política de incrementar el número de docentes masculinos. El presente trabajo muestra que el fundamento teórico de esta política es sumamente frágil. Para obtener una prueba empírica, se ha realizado una amplia investigación en escuelas de educación básica de Holanda involucrando a 5181 alumnos del octavo curso, 251 docentes y 163 escuelas. El estudio confirmó que el género del docente no tiene efecto alguno sobre el rendimiento, las actitudes o las conductas de los alumnos. Los resultados se refieren tanto a los varones como a las niñas, a alumnos de grupos minoritarios o mayoritarios y a niños de estratos socioeconómicos más bajos o más altos.

Резюме - ФЕМИНИЗАЦИЯ НАЧАЛЬНОГО ОБРАЗОВАНИЯ: ВЛИЯНИЕ ПОЛА УЧИТЕЛЕЙ НА УСПЕВАЕМОСТЬ УЧАЩИХСЯ, ИХ ОТНОШЕНИЯ И ПОВЕДЕНИЕ - С середины 1990-х годов феминизация в образовании стала серьезной проблемой. В основе такого утверждения лежит тот факт, что возрастающее число учителей женского пола ведет к снижению мужской роли, что затем может иметь негативные последствия на успеваемость и поведение, в частности, мальчиков. По этой причине в настоящее время в ряде стран проводится политика увеличения числа учителей мужского пола. В данной статье показывается, что теоретическое обоснование такой политики является достаточно слабым. Для эмпирического подтверждения этого положения было проведено широкомасштабное исследование в голландских начальных школах, которое охватило 5181 учащегося восьмого класса, 251 учителя и 163 школы. Данное исследование подтвердило, что пол учителей не влияет ни на успеваемость, ни на отношения или поведение учащихся. Эти данные относятся как к мальчикам, так и к девочкам, к учащимся из представителей меньшинств и большинства, к детям из более низкой и высокой социально-экономической среды.

For a few centuries now, there has been concern about the differences in the school careers of boys versus girls (Frank et al. 2003). The discussion with regard to such is conducted from different perspectives depending on the social-political and economic context (Skelton 2001). And the attention devoted to the topic also varies from country to country. Compared to the USA, UK and Australia, the topic has moved onto the agenda in the 
Netherlands rather late and the reactions are reserved, defensive, indifferent or negative (Veendrick et al. 2004). The labelling of the topic also varies with the position which is adopted and can thus vary from "gender differences," "gender gap" or "differential levels of achievement for girls versus boys" to "the girls" problem" - on the one hand - and more recently "the boys' problem," "failing boys" or "underachieving boys" - on the other hand (Smith 2003; Younger et al. 2002).

The discussion of differences in the school careers of boys versus girls involves a number of fundamental aspects. One question concerns the extent to which the achievement of boys actually differs from the achievement of girls. With regard to the situation in England, Francis and Skelton (2005) relativise the issue by pointing out that any differences according to sex are generally much smaller than differences according to ethnicity, race or social milieu - with the latter family characteristics thus proving much more relevant than the sex of the pupil. There is also discussion of whether the sex differences have increased or decreased over the years. According to Gillborn and Mirza (2000), the difference has increased in favour of girls. Gorard et al. (2001), however, doubt whether boys have ever achieved better than girls over the past 25 years. Smith (2003) finds the "moral panic" which has arisen when boys were most recently found to achieve less than girls to be quite curious. From a feminist perspective, a reaction can be expected along the lines of "Well done, girls!" but, instead, measures have been immediately undertaken to bring the level of achievement back to "standard" for boys. Apparently something must be done about the lead which girls now have and the present differences must be obliterated according to the "male repair agenda".

With regard to all this discussion and critique, it should be added that whether or not one can actually speak of a "boys' problem" is very much the question. According to van Langen and Dekkers (2005), the topic is typically not considered in sufficient detail and the conclusion should rather be that boys perform better than girls with regard to some aspects of education (e.g., maths and science subjects) while girls perform better than boys with regard to other aspects (e.g., language, behaviour). It also appears that the phase in the school careers of pupils should be considered as well as the country in question as major differences have been found to occur along these lines (DfES 2004, Freeman 2004; OECD 2004a; Warrington and Younger 2000).

The panic which has broken out since the results of a number of studies have shown boys to now have an educational delay with respect to girls has prompted the undertaking of concrete "repair" measures in a number of countries (Carrington and Skelton 2003; Ehrenberg et al. 1995; Frank et al. 2003; Skelton 2003). On the parts of the relevant governments, the idea has taken root that an important cause of the delay must be sought in the feminization of education. What is meant is that the percentage of women teaching is constantly increasing at the cost of the percentage of men 
(OECD 2004b; Siongers 2002; van Eck et al. 2004). And as a result of this development, the education itself - that is, the content which is imparted and the manner in which this is done - is assumed to be increasingly more feminine. A further consequence is a growing absence of male role models for boys at school. In such countries as England, Australia and the USA, the governments thus see expansion of the number of male teachers to be a panacea for the recalcitrant behaviour and low levels of achievement currently observed among boys (Ailwood 2003). Male role models at school can present young boys with examples of alternative (i.e., more adjusted) forms of masculinity and thereby turn the negative attitudes of boys with regard to education and school today possibly around (e.g., DEST 2003; DfES 2003; House of Representatives 2002).

\section{Theoretical foundations}

From a feminist point of view, considerable critique has been put forward with respect to the aforementioned vision. According to Carrington and Skelton (2003), the notion of a "role model" can be understood from a number of different perspectives and is typically not considered critically. A clear theoretical framework to justify and motivate the strategies being used to attain more male teachers is also lacking. And one can definitely ask, according to the preceding authors, whether young people - and particularly boys - even want to identify with teachers and thus view their teachers as role models. It is also the case that just as male teachers do not always constitute a suitable role model for boys, female teachers do not always constitute a suitable role model for girls. Furthermore, such matching according to sex may simply reinforce and strengthen stereotypes at times. To be viewed as a role model by their pupils, teachers must earn respect and admiration. This does not happen automatically, and such respect or admiration often depends on the accessibility, honesty and frankness of the potential role models and their significance for the pupils.

Skelton (2003) has provided yet another major criticism of the assumption underlying the government vision that male teachers provide a positive work-oriented role model for young people. According to Skelton, this vision is based on simplistic and naïve notions, which have been open to debate for quite some time now. The relevant notions have their roots in sex-role socialisation theories, which locate masculinity and femininity separately in men and women, respectively. This unidimensional, essentialist viewpoint cannot, however, sufficiently explain the within-sex differences between men and men, for example, or women and women. The multidimensionality of identity is acknowledged and recognised to a greater extent today and thereby the determination of masculinity and femininity by such characteristics as social milieu, sexual orientation, religion, age, race/ethnicity and - of course - biological sex. Smith (2003) points out that the influence of the peer group appears to stand central in the roles, which boys adapt at 
school today. And in such a manner, a conflict may arise between the demands of the school and the curriculum (e.g., obedience, passivity), on the one hand, and the culturally pedagogically determined need for boys to behave in a masculine manner (e.g., display macho and assertive behaviour), on the other hand.

Baily (1996) has asked if we should even speak of the feminization of education at all. Perhaps when one simply examines the number of female teachers, indeed. But when one examines the specific nature of the education being provided by male versus female teachers, whether education is really being feminised is very much open to question. According to Baily, the character of a school is generally determined by those with the most responsibility and power (i.e., headteachers, governors) and therefore mostly by men. Given that management theory has become popular within the field of education, moreover, masculine characteristics such as leadership and authority are increasingly being emphasised. Contrary to what is often argued today, male values appear to predominate within schools.

Sabbe (2004) further suggests that the motive underlying attempts to increase the number of male teachers actually contains a contradiction. On the one hand, it is asserted that men present a different type of personality from women and that only men can thus provide a role model for boys (i.e., boys have specific interests and needs which can only be met by male teachers). On the other hand, it is asserted that the presence of men within the educational profession provides a non-stereotypic image for boys - namely, that not only women but also men can educate and nurture.

\section{Empirical evidence}

For a topic which has led to so much discussion over the past few decades as "the boys' problem," one can expect considerable empirical research to be available to justify the theoretical assumptions and government policy with regard to such. However, this appears to not to be the case. According to Skelton (2003: 207): "A major problem, then, for the current initiatives is that they are not based on any research evidence and therefore lack clear direction." Smith (1999: 2) further observes that opinions and debates can "become accepted as commonsense [while] other issues are silenced and excluded." While considerable research has been conducted on the differences between boys and girls and some research has been conducted on the differences between male and female teachers, the link between the two - namely, the relation between the sex of the teachers and the achievement, attitudes and behaviours of their male and female pupils - has only been examined sporadically. The focus of any research along these lines is also generally on secondary education, and the attitudes and achievement of pupils with respect to maths and science subjects. Research concerned with achievement in other domains, pupil behaviour and the attitudes of pupils at the level of 
primary education is rare. In the following, the results of the few empirical studies available at this time will further be considered.

Ehrenberg et al. (1995) analysed data from the American National Educational Longitudinal Study (NELS) for 3000 pupils in the eighth and tenth grades. In addition to the sex of the pupils and teachers, their ethnic origin was also taken into consideration. Both achievement tests for history, reading, maths and physics and teacher judgements were considered. It was attempted to explain the differences in the progress of the pupils between the eighth and tenth grades on the different measures. In doing this, not only the sex of the eighth-grade teachers and the tenth-grade teachers was taken into consideration but also the sex of the teachers for the two grades considered together. With regard to the achievement tests, the analyses showed neither the sex nor the ethnicity of the teachers to have an effect and no differences to concern the sex or ethnicity of the pupils. With regard to the teacher judgements, girls were judged consistently higher than boys with a significant relation to the sex and ethnicity of the teacher also found in some cases. Black and Hispanic pupils were evaluated more positively by teachers with the same ethnic background, and white female teachers generally evaluated both boys and girls more positively than white male teachers did. The sex and ethnicity of the teacher did not make a difference for the test results, thus, but sometimes made a difference for the teacher judgements.

Hopf and Hatzichristou (1999) conducted a study of Greek primary and secondary schools. Some 2000 pupils and 65 teachers participated in this study which was concerned with teacher judgements of the academic and psycho-social competence of their pupils. Of particular interest were the associations between the pupils in a particular year and the teacher who taught them during that year. Several significant effects were found for the sex of the teachers on their judgements of the academic and psycho-social competence of their pupils and for both primary as well as secondary schools. Girls were generally evaluated more positively than boys. And significant statistical interactions between the sex of the teacher and the sex of the pupil were also found. Male primary-school teachers judged boys, for example, to have interpersonal problems more often than female primaryschool teachers, and teacher evaluations of intrapersonal behaviour (e.g., judgements of shyness) for secondary-school pupils of the opposite sex were generally more positive than for secondary-school pupils of the same sex.

Li (1999) conducted a review study of the effects of the sex of the teacher on boys and girls for the subject of maths in secondary schools. Only a very few studies conducted in mainly developing countries could be found, and sex of the teacher was found to make a difference in only a few of these studies. In some studies, men were generally found to teach maths with greater success than women. In other studies, girls were found to attain higher maths scores when taught by female as opposed to male teachers. And in still other studies, the sex of the teacher was not found to make a difference. 
Siongers (2002) studied Belgian secondary education. She analysed repeating a year, achievement test results and attitude with respect to maths in the second year in addition to various behavioural and attitudinal characteristics in the sixth year. The results showed that the percentage of female teachers within the school did not influence repetition of a year for either boys or girls. An effect of the sex of the teacher was not found for pupil achievement in any of the five maths domains distinguished and also not for boys versus girls when analysed separately. The same held for maths attitudes. In the analyses of the other behavioural and attitudinal characteristics such as sense of public responsibility and sense of well-being, the percentage of female teachers within the school was again used as the measure for the sex of the teachers. No relations were found to exist for girls; for boys, the percentage of female teachers was found to affect the pupils' work attitude to some extent.

\section{Research questions}

In different countries, the feminization of education is of strong interest. In the Netherlands, such interest is only recent. A survey recently conducted on the behalf of the Dutch teachers' union showed that almost $75 \%$ of the primary-school personnel viewed feminization as a problem (Sikkes 2004). Some $55 \%$ of the males perceived feminization to be a threat to the quality of education while only $40 \%$ of the females did so. Some $66 \%$ of the sample of teachers were of the opinion that feminization is bad for the social-emotional development of boys as boys clearly need - in their opinion - male role models.

Those are the research results with regard to the opinions of the people involved. But what about the actual facts? In a number of review articles concerned with the feminization of education, an attempt has been made to lay an empirical foundation (Timmerman and van Essen 2004). The conclusion, however, is that international research on the alleged negative effects of feminization is virtually non-existent. In the Netherlands, according to the aforementioned authors, no studies have been conducted whatsoever on the consequences of the feminization of education. The purpose of the present study therefore was to fill the gap alluded to above and answer the following questions.

1. What is the actual distribution of male and female personnel in primary education? Do differences in the percentages of males versus females exist for different functions or years being taught?

2. Are there differences between male and female teachers with respect to individual background characteristics, class characteristics and/or didactic characteristics?

3. Are there differences in the cognitive and non-cognitive competencies of boys versus girls? 
4. Does a relation exist between the differences in the competencies of the pupils and the sex of the teachers who are teaching them? If so, are there also relations to the sex, ethnic origin and/or social milieu of the pupils? And what relations exist between various pupil characteristics and those characteristics for which male and female teachers have been found to differ from each other?

The results of the present research will be considered per question below.

\section{Men and women in primary education}

\section{Male and female educational personnel according to function}

In Table 1, the national percentages of female primary-school personnel according to function is presented for a number of consecutive school years (SBO 2006).

From Table 1, it can be deduced that only a very small percentage of headteachers are female; in 2004, this was $23 \%$. For deputy heads, the distribution of the sexes is more balanced: $45 \%$ of the personnel are female. Once again, little or no change in this situation can be perceived. For the teaching personnel, a very, very gradual increase in the percentage of females can be observed. In 2004, $84 \%$ of the teachers were female. Finally, for the support staff, a very gradual increase in the percentage of females can again be seen.

The ratio male to female teaching personnel per year

It is well-known that the distribution of male and female teaching personnel across years is unequal. However, there are no national statistics differentiated according to year available for the Netherlands as yet. The data from the nationally representative Primary Education (PRIMA) cohort study in the Netherlands, however, can alter this situation. As part of this study, test and questionnaire data have been collected every 2 years in the early spring from some 60,000 year 2, 4, 6 and 8 pupils from 600 primary schools. ${ }^{1}$ In addition to information on the children, information on the parents, teachers

Table 1. Percentage of female primary-school personnel according to school year and function

\begin{tabular}{llllll}
\hline Function & \multicolumn{5}{l}{ School year } \\
\cline { 2 - 6 } & 2000 & 2001 & 2002 & 2003 & 2004 \\
\hline Headteacher & 15 & 18 & 20 & 22 & 23 \\
Deputy head & 46 & 44 & 44 & 44 & 45 \\
Teacher & 80 & 81 & 82 & 83 & 84 \\
Support staff & 76 & 76 & 77 & 78 & 77 \\
\hline
\end{tabular}


Table 2. Percentage female primary-school teachers according to school year and academic level

\begin{tabular}{lllll}
\hline Academic level & \multicolumn{2}{l}{ School year } & & \\
\cline { 2 - 5 } & 1996 & 1998 & 2000 & 2002 \\
\hline Year 2 & 97 & 98 & 98 & 98 \\
Year 4 & 74 & 80 & 83 & 86 \\
Year 6 & 38 & 50 & 54 & 62 \\
Year 8 & 22 & 28 & 37 & 44 \\
\hline
\end{tabular}

and headteachers has also been collected (Driessen et al. 2004). On each measurement occasion, the sex of the teachers responsible for the selected years is also requested, which allows us to examine the distribution of male and female teachers across years. An overview of the percentages of female primary-school teachers according to school year and academic level (i.e., year $2,4,6$, or 8 ) is presented in Table 2 . The information concerns the school years 1996, 1998, 2000 and 2002 - and some 5000 teachers.

Table 2 shows that year 2 is absolutely the domain of female teachers. Only about $2 \%$ of the year 2 teachers are male. Two further developments are also revealed. First, the percentage of female teachers decreases with year starting in year 4 . In 1996, $74 \%$ of the year 4 teachers are female, $38 \%$ of the year 6 teachers and only $22 \%$ of the year 8 teachers. Second, the percentage of female teachers can be seen to increase across the four school years: from $74 \%$ to $86 \%$ for year 4 ; from $38 \%$ to $62 \%$ for year 6 ; and from $22 \%$ to $44 \%$ for year 8 . In the traditionally male bastion of year 8 , thus, only slightly more than $50 \%$ of the teachers in 2002 were male. The primary-school teaching personnel in the Netherlands is thus becoming very female very rapidly.

\section{Differences between male and female teachers}

The question here is whether male or female teachers differ with regard to background characteristics, characteristics of the year being taught and didactic characteristics. In order to answer this question, the same data from the PRIMA research were used as for the overview of the percentage of female teachers per year. A number of characteristics on which male and female teachers could possibly differ were selected for examination in greater detail and thereby the provision of a possible explanation for the previously expected differences in the cognitive and non-cognitive competencies of the pupils. In the selection of the characteristics, those shown in the literature to be generally relevant to school effectiveness were considered (cf. Driessen and Sleegers 2000; Scheerens and Bosker 1997). Analyses of variance were 
undertaken to determine whether the male and female teachers differed with regard to the different characteristics. These analyses were conducted for each of the four PRIMA measurement occasions and years 4, 6 and 8 separately, which means a series of 12 analyses. The results were very similar for the different years and measurement occasions, so therefore the discussion will be limited to the most recent figures - those from 2002. An overview of the year 4, 6 and 8 results is presented in Table 3. As can be seen, the table contains the labels for the various characteristics involved in the analyses, the scores according to the sex of the teachers and an indication of significant differences. For all of the characteristics, it is the case that the higher the score, the stronger the characteristic. The scores are presented as percentages or averages and, in the case of averages, the possible score range is also specified. In order to obtain an impression of the size of the differences, the eta correlation coefficients are presented. An eta of 0.15 (or $2.25 \%$ of variance explained) or higher is considered just significant and indicated with a *; an eta of 0.20 (or $4 \%$ of variance explained) or higher is considered both significant and relevant and indicated with a**.

When we consider only significant differences, the results in Table 3 show male and female teachers to differ with regard to educational experience: the men have considerably more years of experience in front of the class than the women. This also holds to just about the same extent for the three different years (i.e., years 4, 6 and 8): men have more than 20 years of experience and women more than 16 years of experience on average. The women report somewhat greater confidence in their own capacities than the men, but only the difference for year 4 proved significant. The women also report greater job satisfaction than the men, but only the difference for year 4 proved significant. The female teachers emphasise cognitive educational objectives to a lesser extent than the male teachers for every year, but only the difference for year 8 was significant. For the remaining characteristics, only a significant difference in the number of occasions on which the pupils are tested was detected: male teachers do this much more frequently in year 6 than female teachers.

When the findings for the four PRIMA measurement occasions are considered together, only a single characteristic leads to systematic and relevant differences between the male and female teachers, namely educational experience. The remainder of the differences are not systematic; that is, the differences do not have the same form for the different years and measurement occasions and/or they do not (always) meet the criterion for significance (i.e., an eta of 0.15 or higher). When a less stringent criterion for significance is adopted, emphasis on cognitive objectives, a duo job (i.e., sharing of a job with a colleague) and job satisfaction - although information on the latter characteristic was not available on all measurement occasions - can also be found to play a role. 
Table 3. Differences between male and female teachers on individual background, class and didactic characteristics according to academic level (averages and percentages; $n=$ absolute number $=100 \%$ )

\begin{tabular}{|c|c|c|c|c|c|c|c|c|c|}
\hline & \multicolumn{9}{|c|}{ Academic level } \\
\hline & \multicolumn{3}{|c|}{ Year $4(n=497)$} & \multicolumn{3}{|c|}{ Year $6(n=475)$} & \multicolumn{3}{|c|}{ Year $8(n=437)$} \\
\hline & Male & Female & eta & Male & Female & Eta & Male & Female & eta \\
\hline Extra training $(\%)$ & 24 & 19 & 0.04 & 17 & 17 & 0.00 & 18 & 20 & 0.04 \\
\hline $\begin{array}{l}\text { Educational } \\
\text { experience (years) }\end{array}$ & 23 & 16 & $0.22 * *$ & 20 & 13 & $0.29 * *$ & 21 & 13 & $0.36 * *$ \\
\hline $\begin{array}{l}\text { Confidence in own } \\
\text { capacities }^{\mathrm{a}}\end{array}$ & 3.24 & 3.51 & $0.18 *$ & 3.43 & 3.52 & 0.09 & 3.57 & 3.67 & 0.09 \\
\hline Job satisfaction ${ }^{\mathrm{a}}$ & 3.57 & 3.78 & $0.16^{*}$ & 3.65 & 3.79 & 0.13 & 3.65 & 3.75 & 0.09 \\
\hline $\begin{array}{l}\text { Emphasis cognitive } \\
\text { objectives }^{\mathrm{a}}\end{array}$ & 2.66 & 2.59 & 0.05 & 2.73 & 2.59 & 0.14 & 2.80 & 2.52 & $0.28 * *$ \\
\hline Combined class $(\%)$ & 28 & 41 & 0.09 & 40 & 47 & 0.07 & 32 & 35 & 0.04 \\
\hline Duo job $(\%)$ & 42 & 56 & 0.10 & 46 & 52 & 0.06 & 47 & 53 & 0.07 \\
\hline $\begin{array}{l}\text { Two teachers in } \\
\text { class at once }(\%)\end{array}$ & 30 & 29 & 0.01 & 23 & 26 & 0.09 & 22 & 17 & 0.06 \\
\hline Class size & 23 & 22 & 0.05 & 24 & 23 & 0.04 & 24 & 23 & 0.06 \\
\hline $\begin{array}{l}\text { Homework } \\
\text { language }(\%)\end{array}$ & 12 & 21 & 0.08 & 33 & 33 & 0.00 & 70 & 70 & 0.01 \\
\hline $\begin{array}{l}\text { Homework } \\
\text { maths }(\%)\end{array}$ & 6 & 8 & 0.03 & 16 & 17 & 0.02 & 52 & 55 & 0.04 \\
\hline $\begin{array}{l}\text { Minutes per } \\
\text { week language }\end{array}$ & 318 & 317 & 0.00 & 320 & 322 & 0.01 & 304 & 322 & 0.09 \\
\hline $\begin{array}{l}\text { Minutes per } \\
\text { week maths }\end{array}$ & 283 & 270 & 0.07 & 295 & 288 & 0.05 & 285 & 286 & 0.01 \\
\hline $\begin{array}{l}\text { Registration of } \\
\text { progress }^{b}\end{array}$ & 2.06 & 2.19 & 0.07 & 2.07 & 2.12 & 0.03 & 2.02 & 2.08 & 0.04 \\
\hline $\begin{array}{l}\text { Minimum objectives } \\
\text { language }(\%)\end{array}$ & 39 & 47 & 0.05 & 41 & 42 & 0.01 & 33 & 38 & 0.05 \\
\hline $\begin{array}{l}\text { Minimum objectives } \\
\text { maths }(\%)\end{array}$ & 46 & 51 & 0.04 & 36 & 36 & 0.00 & 29 & 30 & 0.00 \\
\hline $\begin{array}{l}\text { No whole class } \\
\text { instruction }{ }^{\mathrm{c}}\end{array}$ & 2.10 & 2.24 & 0.10 & 2.18 & 2.31 & .012 & 2.28 & 2.41 & 0.13 \\
\hline Regular testing ${ }^{\mathrm{b}}$ & 1.26 & 1.29 & 0.01 & 1.57 & 1.20 & $0.15 *$ & 1.55 & 1.55 & 0.00 \\
\hline
\end{tabular}

${ }^{\text {a }}$ Range $1-5$.

${ }^{\mathrm{b}}$ Range $0-3$.

${ }^{\mathrm{c}}$ Range $1-3$.

*Just significant.

**Significant and relevant.

\section{Differences between boys and girls}

In order to determine whether boys and girls differ with regard to cognitive and non-cognitive competencies, the PRIMA data were used once again. Of particular interest in this case were the school careers of two cohorts of 
pupils, namely pupils who started in year 1 in 1993 and were thus in year 8 in 2000 and pupils who started in year 1 in 1995 and were thus in year 8 in 2002. Only those pupils who did not repeat a year and not referred for special education were included in theses analyses. In light of the fact that the PRIMA measures were operationalised in the same manner, the two cohorts could be combined. This resulted in a database with 5181 year 8 pupils from the classes of 251 teachers and 163 schools.

For each pupil in the PRIMA study, a few background characteristics and a number of cognitive and non-cognitive competencies are known. A brief description is provided below, and the reader is referred to Driessen et al. (2002 2004) and van der Veen et al. (2004) for further details on the PRIMA sample, instruments and variables (also see Driessen 2002). The following characteristics were considered.

- Sex. (1) boy, (2) girl.

- Ethnicity. Country of birth for the parents: (1) Netherlands, (2) Suriname/ Dutch Antilles, (3) Turkey/Morocco, (4) other foreign.

- Social milieu. Parental level of education: (1) primary education, (2) secondary or vocational education, (3) professional (college) education, (4) higher professional (college) education. Both ethnicity and milieu were obtained from the school administrations and provided by the parents.

- Cognitive competencies. Achievement on standardised language and maths tests.

- Non-cognitive competencies. Information with regard to such comes from two sources: namely, the teachers and the pupils themselves. The teachers evaluated their pupils with respect to the following characteristics: Selfconfidence and the psychological component of this in particular (e.g., panics easily), School well-being (e.g., attends school with reluctance), Work attitude (e.g., quickly thinks that work is completed), Social behaviour (e.g., is often impudent) and Relation with teacher (e.g., feels comfortable with teacher). The pupils evaluated themselves with respect to the following characteristics: Self-confidence and the cognitive dimension of this in particular (e.g., I am one of the best pupils in the class) and Well-being (e.g., I think the boys and girls in my class are nice). While the characteristics of Self-confidence and Well-being were thus measured by both the teachers and the pupils themselves, the content of the measures contained a difference in emphasis. The scores for the characteristics were transformed in such a manner that a higher score consistently indicated a stronger presence of the characteristic in question. For self-confidence, for instance, this was expressed as (1) no confidence to (5) lots of confidence.

In Table 4, an overview of the average scores and eta coefficients for the various competencies of the boys and girls or - more concretely - the achievement, attitude and behaviour variables for male and female year 8 pupils is presented. 
Table 4. Achievement, attitudes and behaviour according to sex of pupils (averages)

\begin{tabular}{|c|c|c|c|c|}
\hline & \multicolumn{2}{|l|}{ Sex } & \multirow[t]{2}{*}{ Total } & \multirow[t]{2}{*}{ eta } \\
\hline & Boy & Girl & & \\
\hline \multicolumn{5}{|l|}{ Test results } \\
\hline Language & 1114 & 1115 & 1114 & 0.02 \\
\hline Maths & 118 & 115 & 117 & 0.14 \\
\hline \multicolumn{5}{|l|}{ Pupil self-assessments } \\
\hline Self-confidence & 3.3 & 3.1 & 3.2 & 0.11 \\
\hline Well-being & 3.6 & 3.9 & 3.7 & $0.15^{*}$ \\
\hline \multicolumn{5}{|l|}{ Teacher assessments } \\
\hline Self-confidence & 3.7 & 3.7 & 3.7 & 0.01 \\
\hline Well-being & 3.8 & 4.0 & 3.9 & 0.14 \\
\hline Work attitude & 3.1 & 3.6 & 3.4 & $0.28 * *$ \\
\hline Social behaviour & 3.4 & 3.7 & 3.6 & $0.22 * *$ \\
\hline Relation with teacher & 3.9 & 4.0 & 4.0 & 0.12 \\
\hline
\end{tabular}

*Just significant.

**Significant and relevant.

The data in Table 4 show that only clear significant differences exist for well-being as judged by the pupils themselves, and work attitude and social behaviour as judged by their teachers with girls consistently scoring higher than boys. Earlier in this section, it was mentioned that the social milieu (i.e., parental level of education) and ethnicity of the pupils were also known. In order to determine whether the scores presented in Table 4 vary within different groups distinguished according to social milieu and ethnicity, two-way analyses of variance were conducted. No interaction effects between the sex of the pupil and social milieu or the sex of the pupil and ethnic origin were found. In other words, the averages for the boys and girls in Table 4 manifest themselves quite similarly within the various milieu and ethnic groups.

\section{Effects of the sex of the teacher on pupils}

In order to answer the key question underlying the present study - namely, does the sex of teachers affect the competencies of primary-school pupils the findings presented above were brought into relation with each other. First, the effect of the sex of the teachers on the competencies of the pupils was determined in one-way analyses of variance. Two-way analyses of variance were then conducted to determine whether one could speak of interaction effects for the sex of the teachers with three pupil characteristics, 
namely sex, ethnicity and social milieu. Using these results, such questions as the following could then be answered.

- Is the effect of the sex of the teachers different for girls as opposed to boys?

- Is the effect of the sex of the teachers different for pupils from very different cultures (e.g., Turkish/Moroccan minority pupils in the Netherlands as opposed to native Dutch pupils or Surinamese/Dutch Antillean minority pupils in the Netherlands as opposed to Turkish/Morrocan pupils)?

- Is the effect of the sex of the teachers different for the children from lower as opposed to higher social milieus?

Next, three-way analyses of variance were conducted with the sex of the teachers, sex of the pupils and either the ethnicity or social milieu of the pupils included. Using these results, the following kinds of questions could then be answered.

- Is the effect of the sex of the teachers different for Turkish/Moroccan girls as opposed to Dutch boys?

- Is the effect of the sex of the teachers different for girls from lower social milieus as opposed to boys from lower social milieus?

Finally, it was attempted to determine whether or not a relation exists to those characteristics on which male and female teachers have been found to differ significantly from each other: the educational experience of the teachers, the degree of emphasis on cognitive objectives and whether a duo job was involved or not.

Inspection of the relevant research literature shows the sex of the teachers to be operationalised in very different manners. To determine the effects of the sex of the teachers, the following three variants were considered.

- The cumulative effect. The total number of male teachers which a pupil has from year 1 through year 8.

- The phase effect. The phase in which the pupil had a male teacher, with the following division employed: neither in year 1 through year 6 nor in years 7 or 8 ; only in year 1 through year 6 but not in years 7 or 8 ; not in year 1 through year 6 and only in years 7 or 8 ; or in both year 1 through year 6 and years 7 or 8 .

- The moment effect. Whether the pupil had a male teacher at the end of primary school and thus in year 8 or not.

\section{The cumulative effect}

In Table 5, an answer is provided to the question of whether the presence of male teachers in primary school leads to different achievement, attitudes and behaviour on the part of year 8 pupils or not. The table contains the average scores for nine aspects of pupil competence. The number of male teachers in 
Table 5. Achievement, attitude and behaviour according to total number of male teachers during pupil school career (averages)

\begin{tabular}{|c|c|c|c|c|c|c|c|c|}
\hline & \multicolumn{6}{|c|}{ Number of male teachers } & \multirow[t]{2}{*}{ Total } & \multirow[t]{2}{*}{ eta } \\
\hline & 0 & 1 & 2 & 3 & 4 & $5 / 6$ & & \\
\hline \multicolumn{9}{|l|}{ Test results } \\
\hline Language & 1114 & 1113 & 1116 & 1116 & 1110 & 1115 & 1114 & 0.07 \\
\hline Maths & 116 & 116 & 117 & 118 & 116 & 117 & 117 & 0.06 \\
\hline \multicolumn{9}{|l|}{ Pupil self-assessments } \\
\hline Self-confidence & 3.2 & 3.2 & 3.2 & 3.2 & 3.2 & 3.2 & 3.2 & 0.02 \\
\hline Well-being & 3.8 & 3.8 & 3.8 & 3.7 & 3.7 & 3.7 & 3.7 & 0.05 \\
\hline \multicolumn{9}{|l|}{ Teacher assessments } \\
\hline Self-confidence & 3.8 & 3.8 & 3.7 & 3.7 & 3.7 & 3.8 & 3.7 & 0.08 \\
\hline Well-being & 4.0 & 4.0 & 3.9 & 3.9 & 3.8 & 3.8 & 3.9 & 0.11 \\
\hline Work attitude & 3.4 & 3.5 & 3.4 & 3.4 & 3.3 & 3.2 & 3.4 & 0.08 \\
\hline Social behaviour & 3.5 & 3.7 & 3.5 & 3.6 & 3.5 & 3.5 & 3.6 & 0.08 \\
\hline Relation with teacher & 4.0 & 4.0 & 3.9 & 3.9 & 3.9 & 3.9 & 4.0 & 0.09 \\
\hline
\end{tabular}

*Just significant.

**Significant and relevant.

practice varied from 0 to 6 per pupil school career and, in light of the limited frequencies for the categories of five and six male teachers, these two categories were combined.

The conclusion which can be drawn on the basis of the results presented in Table 5 is that no statistically significant differences can be detected between those year 8 pupils with exposure to few versus many male teachers during their primary school careers.

Whether one can speak of significant relations when the sex of the pupils, their ethnicity and the social milieu are considered more specifically was next considered. The interaction coefficients from the two-way analyses of variance conducted for this purpose were found to vary from 0.02 to a maximum of 0.10 with the majority of the eta coefficients around 0.05 . These findings reveal no significant interaction effects whatsoever, which means no effect of the number of male teachers on achievement, attitudes or behaviour for either year 8 boys or girls, Dutch pupils versus ethnic minority pupils or pupils from a lower as opposed to higher social milieus. The subsequent three-way analyses of variance also revealed no significant interaction effects, which means that such an absence of effects was also found for year 8 boys versus girls from lower social milieus, for year 8 Turkish/Morrocan boys as opposed to year 8 Dutch girls and so forth. 


\section{The phase effect}

The phase effect pertains to whether the year 8 pupil had a male teacher during the lower and/or higher primary-school years. Just as for the analyses of the number of male teachers all together, the phase in which the pupils had a male teacher did not appear to influence the achievement, attitudes or behaviour of the year 8 pupils. Both the two- and three-way analyses of variance showed no significant interaction effects.

\section{The moment effect}

The average scores for the nine aspects of competence for pupils who had a male versus female teacher during the final year of primary school (i.e., in year 8) were computed. Once again, the results showed no significant effect for the sex of the teachers. The moment results are thus the same as the cumulative and phase results. And once again, the two- and three-way analyses of variance reveal no significant interaction effects.

\section{Additional teacher characteristics}

The results reported up until this point suggest that the sex of the teachers does not contribute to the explanation of differences in the achievement, attitudes or behaviour of primary-school pupils. In addition to the sex of the teachers, however, we also have access to information on three other potentially relevant characteristics: educational experience, emphasis on cognitive objectives and duo job. Male and female teachers were found to differ to some extent on these characteristics, and the question is thus whether these characteristics possibly relate to pupil achievement, attitudes and/or behaviour. Once again, analyses of variance were conducted. However, the three variables were not found to exert an effect on pupil achievement, attitudes or behaviour. Significant interaction effects involving the three potentially relevant teacher characteristics were also not detected.

\section{Summary and conclusions}

In the present study, the question of whether the sex of the teacher influences the achievement, attitudes and behaviour of pupils attending Dutch primary schools stood central. The assumption was namely that as the number of female teachers increases, fewer male role models are available to pupils. The decreased presence of male role models is then assumed to exert a detrimental effect upon the school careers of boys. And boys are thus expected to show a delay with respect to girls. On the basis of this line of reasoning, government action has been undertaken in various countries to obtain more men in the classroom. The "feminization of education" has 
recently led to considerable discussion, particularly from a feminist perspective. Questions are raised with regard to the theoretical foundation for the various presuppositions and the absences of adequate empirical evidence is also frequently pointed out.

In the present study, the Dutch situation was examined and it was tried to attain an answer from a clearly empirical perspective to the question of whether sex of the teacher plays a role or not. Empirical research along these lines has generally been only sporadic and non-existent in the Netherlands up until now. Data from the recent, large-scale, national, primary education cohort study (PRIMA) was used. More specifically, information on 5181 year 8 pupils (i.e., 12-year-olds) and 251 teachers from 163 schools were analysed.

One question must first be answered because it also constitutes the starting point for any further analyses and that is whether the proposed differences between the year 8 boys and girls actually exist or not. If no differences can be detected, then the question of how to explain the differences does not arise. And it should be noted that in the discussion around this topic, the achievement of the pupils stands central. Nevertheless a number of other aspects of potential importance were examined for the achievement of primary-school pupils. Concretely, the following variables were examined: pupil achievement as measured by tests and pupil attitudes and behaviour as evaluated by the pupils themselves and by their teachers. The results showed no significant effects in the language or maths achievement of year 8 boys versus girls. A few small differences were observed for some of the attitudinal and behavioural variables examined - namely well-being, work attitude and social behaviour - and then in favour of the girls.

Despite the non-significance of the preceding results, nevertheless some subsequent analyses were undertaken in an attempt to explain the small differences between the year 8 boys and girls on the basis of the sex of the teachers. In every set of analyses, however, the sex of the teachers was not found to significantly influence the achievement, attitudes or behaviour of the primary-school pupils. This was found to hold for the total number of male teachers the pupils had during their primary-school careers, the phase in which the pupils had male teachers during their primary-school careers (i.e., during the lower and/or higher years) and the sex of the teacher in year 8 (i.e., the final year of primary school). No significant differences were found for male versus female pupils, Dutch versus minority pupils or pupils from lower versus higher social milieus. In other words, no empirical evidence exists at present for policy aimed at halting the feminization of education. More men at the front of the class does not lead to better achievement and/or more favourable attitudes and behaviour on the part of boys or - for that matter - girls.

A number of points should be noted in connection with the foregoing conclusions. A first point is that the present analyses concerned only nondelayed pupils. Obviously those pupils repeating a year and those pupils 
referred for special education should also be considered. It is possible that the sex of the teacher does make a difference for one or the other specific group of pupils. The group of delayed pupils and the group of pupils referred for special education both show an overrepresentation of boys, and it is possible that male teachers handle such problems and at-risk boys differently than female teachers. Unfortunately, the PRIMA database contains an insufficient number of such pupils to allow us to draw reliable conclusions with regard to this issue.

A second point to be noted with respect to the present findings is that they concern only primary-school pupils. The subsequent phases of education have yet to be examined in the Netherlands, and it is certainly possible that significant effects of the sex of teachers may then be found. The secondary-school situation is very different than the primary-school situation. In the Netherlands, only one-third of secondary school teachers are female, which means that the secondary-school situation is clearly dominated by men. Very few women teach maths and science subjects at a secondary-school level, moreover. According to Veendrick et al. (2004), however, the negative attitudes of boys towards education during secondary school may have their roots in the primary-school period. In short, there are ample interesting questions requiring extremely complicated research designs for the future. And with respect to research designs, it should be noted that, in the analyses, a model was assumed in which it is attempted to explain any differences between boys and girls in terms of differences between their teachers. This is the usual approach adopted for educational research purposes and the approach adopted in all of the empirical studies that were discussed. It is nevertheless the question whether such a purely linear approach in which the effect of one characteristic on the other stands central does justice to the complexity of the relations between various characteristics and whether one should not rather speak in terms of coalitions of factors or connections between characteristics.

A final point is that although the present study shows no empirical support for the assumption of detrimental effects due to the feminization of education, there may still be emancipatory motives to pursue a more generally balanced distribution of male and female personnel. This should, however, apply to all functions and not just to teaching or educational support personnel but also to headteachers and management personnel. That is, a call for both more men in teaching and more women in management should perhaps be made.

\section{Acknowledgements}

The research reported on here was financially supported by the Netherlands Ministry of Education. Use was made of data from the PRIMA study, which was subsidised by the Netherlands Organisation for Scientific Research (NWO). 


\section{Note}

1. Dutch primary schools are for 4- to 12-year-old children and thus provide 8 years of education. In years 1 and 2, play occupies a central place. In year 3, formal reading, maths and writing instruction starts. After the final year of primary school or year 8 , the pupils move on to secondary school.

\section{References}

Ailwood, Jo. 2003. A National Approach to Gender Equity Policy in Australia: Another Ending, Another Opening?. International Journal of Inclusive Education 7(1): $19-31$.

Bailey, Lucy. 1996. The Feminization of a School? Women Teachers in a Boys' School. Gender and Education 8(2): 171-184.

Carrington, Bruce, and Christine Skelton. 2003. Re-thinking "Role Models": Equal Opportunities in Teacher Recruitment in England and Wales. Journal of Education Policy 18(3): 253-265.

DEST. 2003. Educating Boys. Issues and Information. Canberra: DEST.

DfES. 2003. Using the National Healthy School Standard to Raise Boys'Achievement. London: DfES.

DfES. 2004. Gender and Achievement. http://www.standards.dfes.gov.uk/genderandachievement/, accessed March 13, 2006.

Driessen, Geert. 2002. School Composition and Achievement in Primary Education: A Large-scale Multilevel Approach. Studies in Educational Evaluation 28(4): 347-368.

Driessen, Geert, and Peter Sleegers. 2000. Consistency of Teaching Approach and Student Achievement: An Empirical Test. School Effectiveness and School Improvement 11(1): $57-79$.

Driessen, Geert, Annemarie van Langen, and Hermann Vierke. 2002. Basisonderwijs: Veldwerkverslag, Leerlinggegevens en Oudervragenlijsten. Basisrapportage PRIMACohortonderzoek. Vierde Meting 2000-2001 [Pupil Variables. Primary Education: Basic Report PRIMA Cohort Study. Fourth Measurement Round 2000-2001]. Nijmegen: ITS.

Driessen, Geert, Annemarie van Langen, and Hermann Vierke. 2004. Basisonderwijs: Veldwerkverslag, Leerlinggegevens en Oudervragenlijsten. Basisrapportage PRIMACohortonderzoek. Vijfde Meting 2002-2003 [Pupil Variables. Primary Education: Basic Report PRIMA Cohort Study. Fifth Measurement Round 2002-2003]. Nijmegen: ITS.

Ehrenberg, Ronald, Daniel Goldhaber, and Dominic Brewer. 1995. Do Teachers' Race, Gender, and Ethnicity Matter? Evidence from the National Educational Longitudinal Study of 1988. Industrial and Labor Relations Review 48(3): 547-560.

Francis, Becky, and Christine Skelton 2005. Reassessing Gender and Achievement. Questioning Contemporary Key Debates. London and New York: Routledge.

Frank, Blye, Michael Kehler, Trudy Lovell, and Kevin Davison. 2003. A Tangle of Trouble: Boys, Masculinity and Schooling - Future Directions. Educational Review 55(2): 119-133. 
Freeman, Catherine. 2004. Trends in Educational Equity of Girls and Women. Washington, DC: US Department of Education.

Gillborn, David, and Heidi Mirza 2000. Educational Inequality. Mapping Race, Class and Gender. A Synthesis of Research Evidence. London: Ofsted.

Gorard, Stephen, Gareth Rees, and Jane Salisbury. 2001. Investigating the Pattern of Differential Achievement of Boys and Girls at School. British Educational Research Journal 27(1): 125-139.

Hopf, Dieter, and Chryse Hatzichristou. 1999. Teacher Gender-related Influences in Greek Schools. British Journal of Educational Psychology 69: 1-18.

House of Representatives. 2002. Boys: Getting it Right. Report on the Inquiry into the Education of Boys. Canberra: House of Representatives.

Li, Qing. 1999. Teachers' Beliefs and Gender Differences in Mathematics: A Review. Educational Research 41(1): 63-76.

OECD. 2004a. Learning for Tomorrow's World - First Results from PISA 2003. Paris: OECD.

OECD. 2004b. Education at a Glance 2004. OECD Indicators 2004 Edition. Paris: OECD.

Sabbe, Elien. 2004. Secondary School Pupils' Perceptions of their Male and Female Teachers. Paper AERA Annual Meeting, San Diego, CA, USA, 22-27 March 2004.

SBO. 2006. Jaarboek 2005. Onderwijsarbeidsmarkt in beeld [Year book 2005. Education and Labour Market]. Den Haag: Sectorbestuur Onderwijsarbeidsmarkt.

Scheerens, Jaap, and Roel Bosker 1997. The Foundations of Educational Effectiveness. Oxford: Pergamon.

Sikkes, Robbert. 2004. Poen, Status en de Tere Jongensziel. Enquête over Vervrouwelijking Onderwijs [Money, status and the tender boy's soul]. Het Onderwijsblad 8(7): 16-23.

Siongers, Jessy. 2002. De Gevolgen van de Feminisering van het Leerkrachtenberoep in het Secundair Onderwijs: Een Empirische Analyse [The consequences of the feminization of the teacher profession]. Brussel: Vrije Universiteit Brussel.

Skelton, Christine. 2001. Schooling the Boys. Masculinities and Primary Education. Buckingham: Open University Press.

Skelton, Christine. 2003. Male Primary Teachers and Perceptions of Masculinity. Educational Review 55(2): 195-209.

Smith Janet. 1999. We Need More Males in Primary Teacher Education! Or Do We? Paper Australian Association for Research in Education Conference, Melbourne, November 1999.

Smith, Emma. 2003. Failing Boys and Moral Panics: Perspectives on the Underachievement Battle. British Journal of Educational Studies 51(3): 282-295.

Timmerman, Greetje, and Mineke Essenvan. 2004. De Mythe van het "Vrouwengevaar"'The myth of the "Women's Danger"]. Pedagogiek 24(1): 57-71.

van der Veen, Ineke, Arjan van der Meijden, and Guuske Ledoux. 2004. School en Klaskenmerken Basisonderwijs. Basisrapportage PRIMA-Cohortonderzoek. Vijfde Meting 2002-2003 [School Variables. Primary Education: Basic Report PRIMA Cohort Study Fourth Measurement Round 2002-2003]. Amsterdam: SCO-Kohnstamm Instituut. 
van Eck, Edith, I. Heemskerk, and A. Vermeulen. 2004. Paboys Gezocht! Wat Maakt de Pabo en het Werken op de Basisschool Aantrekkelijker voor Mannen? [Wanted Male Teacher Students!]. Amsterdam: SCO-Kohnstamm Instituut.

van Langen, Annemarie, and Hetty Dekkers. 2005. Cross-National Differences in Participating in Tertiary Science, Technology, Engineering and Mathematics Education. Comparative Education 41(3): 329-350.

Veendrick, Laurenz, Louis Tavecchio, and Jeannette Doornenbal. 2004. Jongens als Probleem. Inleiding bij het Themadeel [Boys as a Problem]. Pedagogiek 24(1): 12-22.

Warrington, Molly, and Michael Younger. 2000. The Other Side of the Gender Gap. Gender and Education 12(4): 493-508.

Younger, Michael, Molly Warrington, and Ros McLellan. 2002. The "Problem" of "Under-Achieving Boys": Some Responses from English Secondary Schools. School Leadership \& Management 22(4): 389-405.

\section{The author}

Geert Driessen is a senior educational researcher at the Institute for Applied Social Sciences (ITS) of the Radboud University Nijmegen. His major research interests include education in relation to ethnicity/race, social milieu and sex/gender, parent participation, school choice, religious schools, Islamic schools, and integration and segregation.

Contact address: ITS - Institute for Applied Social Sciences, Radboud University Nijmegen, P.O. Box 9048, 6500 KJ, Nijmegen, The Netherlands. E-mail: g.driessen@ its.ru.nl; website: www.geertdriessen.nl. 